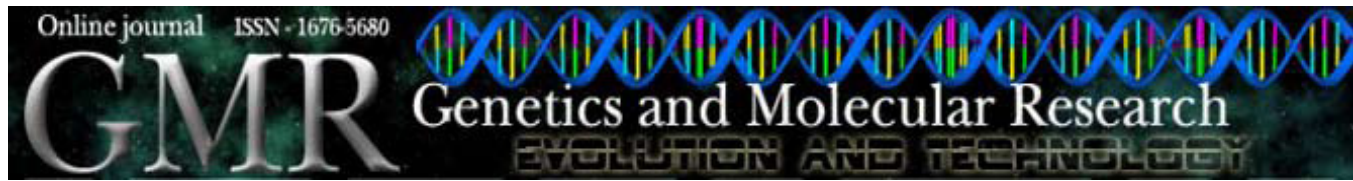

Methodology

\title{
An inexpensive and rapid method for extracting papilionoid genomic DNA from herbarium specimens
}

\author{
M. Riahi ${ }^{1}$, S. Zarre ${ }^{1}$, A.A. Maassoumi ${ }^{2}$, F. Attar ${ }^{1}$ and S. Kazempour Osaloo ${ }^{3}$ \\ ${ }^{1}$ Department of Plant Sciences, School of Biology, College of Science, \\ University of Tehran, Tehran, Iran \\ ${ }^{2}$ Research Institute of Forests and Rangelands, Tehran, Iran \\ ${ }^{3}$ Department of Plant Biology, Faculty of Basic Science, \\ Tarbiat Modaress University, Tehran, Iran \\ Corresponding author: M. Riahi \\ E-mail: riahi@khayam.ut.ac.ir
}

Genet. Mol. Res. 9 (3): 1334-1342 (2010)

Received march 18, 2010

Accepted May 18, 2010

Published July 13, 2010

DOI 10.4238/vol9-3gmr839

\begin{abstract}
Three DNA extraction protocols were compared for their ability to yield DNA from the leaves of herbarium specimens of nine species from nine genera of the Papilionoideae. We tested two protocols that use classic procedures for lysis and purification with cetyl trimethylammonium bromide (CTAB); a third protocol used a Nucleospin Plant kit. DNA obtained from all three procedures was quantified and tested by PCR. Test results indicated the superiority of one of the CTAB protocols. We made some modifications, developing a protocol that produced highquality DNA from all nine species. The modification involved the use of a lower EDTA concentration (20 $\mathrm{mM}$ instead of $50 \mathrm{mM}$ ) and a higher $\beta$-mercaptoethanol concentration ( $1 \%$ instead of $0.4 \%)$ in the extraction buffer. The modified protocol avoids the necessity for
\end{abstract}


a second DNA precipitation step. This new CTAB protocol includes the use of $1.4 \mathrm{M} \mathrm{NaCl}, 20 \mathrm{mM}$ EDTA and $1 \% \beta$-mercaptoethanol in the extraction; DNA precipitation time is reduced. A reduction in contaminating metabolites (such as PCR inhibitors) in the sample mixtures and lower costs for reagents are characteristics of this modified protocol; the cost of analysis per sample was lowered, compared to previous options. The quality of DNA was suitable for PCR amplification. This is a practical alternative to more difficult, time-consuming and expensive protocols.

Key words: Papilionoideae; DNA extraction; Herbarium specimen; PCR amplification; CTAB

\section{INTRODUCTION}

The subfamily Papilionoideae (Fabaceae) comprises more than 476 genera and 13,855 species, ranging from large trees to annual herbs and distributed worldwide (Mabberley, 1997). The subfamily includes horticultural varieties and many species harvested as crops for oils, fuel, timber, medicine, and chemicals.

The isolation of high-quality DNA is important in any molecular biology work because contaminants such as proteins, polyphenols, and polysaccharides may interfere with enzymes such as restriction enzymes (in blotting techniques) and Taq polymerase (in polymerase chain reaction [PCR]) (Ausubel et al., 1994; Pirttilä et al., 2001).

To obtain good-quality DNA, the utilization of fresh or frozen plant tissue is ideal (Sytsma et al., 1993). With the expansion of molecular techniques, herbarium collections have become relatively widely used because of the easy accessibility and richness of herbarium collection. However, DNA isolation from dried specimens usually requires some modifications of frequently used protocols, because these extraction protocols result in low DNA yield and quality (Rogers, 1994).

In this study, three extraction techniques were compared using dry herbarium specimens of the Papilionoideae collected from 1950-2005. We also optimized the protocol that provided the greatest yield of DNA. During this optimization, we focused on developing a fast, reliable, and low-cost protocol for the extraction of DNA suitable for PCR amplification, from some genera of the Papilionoideae.

\section{MATERIAL AND METHODS}

\section{Plant material}

Nine species, each representing one genus of the Papilionoideae (four tribes), were analyzed (Appendix). The dried leaves used came from herbarium specimens of various ages catalogued in the herbarium of Tehran University.

\section{Testing DNA extraction protocols}

In all DNA extraction protocols, $0.1 \mathrm{~g}$ frozen leaf tissue was utilized from each sam- 
ple, which was ground in liquid nitrogen. The frozen powder was immediately transferred to $2.0-\mathrm{mL}$ microcentrifuge tubes and stored at $70^{\circ} \mathrm{C}$ or processed at once. Equipment and materials used in all protocols were: 1) mortar and pestle; 2) 1.5- and 2.0-mL microcentrifuge tubes; 3) liquid nitrogen; 4) water bath $\left(60^{\circ}\right.$ or $\left.65^{\circ} \mathrm{C}\right)$; 5) centrifuge.

\section{DNA extraction Protocol A (Nucleospin Plant kit)}

This method uses silica gel-membrane technology and simple-spin procedures to isolate high-quality DNA.

Solutions:

- Nucleospin Plant kit buffers (C1, C4, CW, C5, CE)

- $100 \% \mathrm{EtOH}$

Protocol:

Extraction was performed according to the Nucleospin protocol with a small modification for dried samples. For lysis of the cells, we used $450 \mu \mathrm{L} \mathrm{C1}$ buffer (instead of 400 $\mu \mathrm{L}$ ), $40 \mu \mathrm{L}$ CE buffer (instead of $100 \mu \mathrm{L}$ ) for increasing the final DNA concentration, and a longer elution time (10 $\mathrm{min})$.

\section{DNA extraction Protocol B (modified - Doyle and Doyle, 1990)}

Total DNA from leaf tissue was extracted in cetyl trimethylammonium bromide (CTAB) isolation buffer according to the protocol of Doyle and Doyle (1990), which has been successfully utilized with many plant species. This protocol was based on lysis and purification with $\mathrm{CTAB}$, which selectively precipitated DNA while maintaining the solubility of many polysaccharides. This protocol utilized polyvinylpyrrolidone (PVP) to bind phenolic compounds. CTAB must be carefully washed out.

Solutions:

- Extraction buffer: 2\% CTAB, $100 \mathrm{mM}$ Tris-HCl, pH 7.5, $1.4 \mathrm{M} \mathrm{NaCl}, 20 \mathrm{mM}$ ethylene diamine tetraacetic acid (EDTA), $\mathrm{pH}$ 8.0. Add 2\% $\beta$-mercaptoethanol and 2\% PVP-40, immediately prior to use.

- Chloroform:isoamyl alcohol, 24:1 (CIA).

- Isopropanol

- $70 \% \mathrm{EtOH}$

- TE-RNase solution: 10 mM Tris-HCl, 1 mM EDTA, pH 8.0, 10 mg/mL RNase.

Protocol:

1. To each ground leaf sample, add $1 \mathrm{~mL}$ extraction buffer and incubate samples for 1 $\mathrm{h}$ at $60^{\circ} \mathrm{C}$ with occasional swirling.

2. Cool samples at room temperature, add $600 \mu \mathrm{L}$ CIA and mix gently for $5 \mathrm{~min}$.

3. Centrifuge at $10,000 \mathrm{rpm}$ for $15 \mathrm{~min}$. Transfer the supernatant to a new tube and add an equal volume of isopropanol. Mix gently and incubate at $-20^{\circ} \mathrm{C}$ overnight.

4. Centrifuge for $15 \mathrm{~min}$ at $10,000 \mathrm{rpm}$. Wash the pellet with $70 \%$ ethanol and centrifuge for $10 \mathrm{~min}$. Repeat this wash once or twice.

5. Dry the DNA and dissolve the pellet in 20-50 $\mu \mathrm{L}$ (according to your quantity) TERNase solution. Incubate for $1 \mathrm{~h}$ at $37^{\circ} \mathrm{C}$. 


\section{DNA extraction Protocol C (modified - Murray and Thompson, 1980)}

As a second 'classical' method, we used the protocol of Murray and Thompson (1980) as modified by Cota-Sánchez et al. (2006). This protocol has been utilized to extract DNA from fresh, frozen, silica gel-dried, and herbarium material from a variety of plant families.

Solutions:

- Extraction buffer: $2 \%$ CTAB, $100 \mathrm{mM}$ Tris- $\mathrm{HCl}, \mathrm{pH} 7.5,1.4 \mathrm{M} \mathrm{NaCl}, 50 \mathrm{mM}$ EDTA, $\mathrm{pH}$ 8.0. Add $0.4 \% \beta$-mercaptoethanol immediately prior to use.

- CIA, 24:1

- Isopropanol

- Tris-EDTA (TE)

- RNase, $10 \mathrm{mg} / \mathrm{mL}$

- Sodium oxaloacetate (NaOAc), $2.5 \mathrm{M}$

- EtOH, 70 and 95\%

Protocol:

1. Add $750 \mu \mathrm{L}$ of extraction buffer to 1.5 -mL microcentrifuge tubes. Add a stipule-tip of powdered leaf to each tube and swirl well.

2. Incubate sample for $1 \mathrm{~h}$ at $60^{\circ} \mathrm{C}$, with swirling every $15 \mathrm{~min}$.

3. Add $700 \mu \mathrm{L}$ CIA and mix thoroughly. Centrifuge for $15 \mathrm{~min}$ at 10,000 rpm.

4. Transfer the aqueous phase to a new tube, add 0.33 vol. ice-cold isopropanol, and store at $-30^{\circ} \mathrm{C}$ for at least $1 \mathrm{~h}$. Centrifuge for $15 \mathrm{~min}$ at $10,000 \mathrm{rpm}$ at room temperature.

5. Discard supernatant without disturbing the pellet. Resuspend pellet in 100-200 $\mu \mathrm{L}$ TE. Add 1-2 $\mu \mathrm{L} 10 \mathrm{mg} / \mathrm{mL}$ RNase. Add 0.1 vol. $2.5 \mathrm{M} \mathrm{NaOAc}$ and 2 vol. ice-cold $95 \%$ ethanol, and store at $-20^{\circ} \mathrm{C}$ for $30 \mathrm{~min}$. Centrifuge for $5 \mathrm{~min}$ at $10,000 \mathrm{rpm}$. Discard supernatant.

6. Wash pellet with $1 \mathrm{~mL} \mathrm{70 \%} \mathrm{ethanol.} \mathrm{Centrifuge} \mathrm{for} 4 \mathrm{~min}$ at 10,000 rpm and pour off ethanol.

7. Resuspend pellet in 100-200 $\mu \mathrm{L}$ TE.

\section{DNA extraction Protocol D (modified - Cota-Sánchez et al., 2006)}

We made some modifications in the protocol of Cota-Sánchez et al. (2006).

Solutions:

- Extraction buffer: 2\% CTAB, 100 mM Tris-HCl, pH 7.5, 1.4 M NaCl, 20 mM EDTA, $\mathrm{pH}$ 8.0. Add $1 \% \beta$-mercaptoethanol immediately prior to use.

- CIA, 24:1

- Isopropanol (chilled)

- Tris-EDTA (TE): 10 mM Tris-HCl, 1 mM EDTA, pH 8.0

- $70 \% \mathrm{EtOH}$

Protocol:

1. Preheat CTAB buffer to $65^{\circ} \mathrm{C}$. Add $800 \mu \mathrm{L}$ CTAB buffer and $800 \mu \mathrm{L}$ to $1.5-\mathrm{mL}$ microcentrifuge tubes, add a stipule-tip of leaf powdered to each tube, and mix well.

2. Incubate in a water bath at $65^{\circ} \mathrm{C}$ for $15 \mathrm{~min}$ with occasional swirling.

3. Cool sample to room temperature by keeping tube on ice. Add $750 \mu \mathrm{L}$ CIA to each tube and invert 50 times. Centrifuge for $15 \mathrm{~min}$ at 10,000 rpm. Transfer the supernatant to a new tube and repeat CIA extraction. 
4. Transfer the supernatant to a new tube with 0.7 vol. ice-cold isopropanol and invert gently 10 times. Centrifuge for $15 \mathrm{~min}$ at 10,000 rpm. For samples with clear pellets, discard supernatant without disturbing the pellet, and for samples with gelatinous material above the pellet, remove all but leave the gelatinous portion and pellet intact.

5. Wash pellet with $1 \mathrm{~mL} \mathrm{70 \%} \mathrm{ethanol.} \mathrm{Centrifuge} \mathrm{for} 10 \mathrm{~min}$ at $10,000 \mathrm{rpm}$ and pour off ethanol; repeat this step. Vacuum-dry pellet. Do not over-dry.

6. Resuspend pellet in 50-20 $\mu \mathrm{L}$ TE. Incubate at $37^{\circ} \mathrm{C}$ for $30 \mathrm{~min}$.

\section{Comparison of efficiency of the extraction protocols}

After extraction, DNA was visualized on a $1 \% \mathrm{EtBr}$ agarose gel. The quality of DNA was estimated by measuring the $\mathrm{A}_{260 / 280}$ (absorbance) ratio with a spectrophotometer (Hitachi U-200). Quality and performance of the isolated DNA was assessed by PCR amplification of the internal transcribed spacer (ITS) region of ribosomal DNA and non-coding $\operatorname{trn} \mathrm{L} / \mathrm{F}$ region of the chloroplast genome. Primers ITS4 and ITS5 were used to amplify a 700-bp fragment of the ITS region. PCR amplification of the $t r n \mathrm{~L} / \mathrm{F}$ region involved primer set $\mathrm{E} / \mathrm{F}$, which targets a fragment of $\sim 400 \mathrm{bp}$. The ITS and $t r n \mathrm{~L} / \mathrm{F}$ regions were amplified using the primers and PCR conditions described by White et al. (1990) and Taberlet et al. (1991), respectively.

\section{RESULTS AND DISCUSSION}

In an attempt to isolate pure nuclear DNA from some historical herbarium specimens of the Papilionoideae, we tried some published nuclear DNA isolation protocols.

The samples obtained with all protocols were evaluated according to DNA quality, color, spectral absorbance ratio, final concentration $(\mathrm{ng} / \mu \mathrm{L})$, and PCR amplification (Table 1). For each type of plant sample, six replicates were subjected to spectrophotometric measurements.

Most of the herbarium specimens yielded no DNA or DNA with a high level of degradation, low $\mathrm{A}_{260 / 280}$ ratio and low final concentration using Protocol A (Figure 1A), and PCR amplifications were not successful with samples that exhibited highly degraded DNA. The DNA isolated by Protocol B might have contained contaminants of CTAB that can lead to an overestimation of the yield in the spectrophotometric measurements, which is caused by interference of residual CTAB in samples (Figure 1B, Table 1) (Drábková et al., 2002). The DNA solutions from some of the samples were colored (yellowish or dark) when extracted using Protocols B and C, mainly due to fast oxidation of the extract. Such samples were found to have a shorter storage life and were difficult to amplify (Table 1) (Lodhi et al., 1994).

The method described by Cota-Sánchez et al. (2006) gave satisfactory results for most samples, with successful purification and a lower amount of potential contaminations, compared to the other techniques (Figure 2A, Table 1). DNA extracted with these protocols was of sufficient quality to amplify PCR fragments of up to 700 bp (Figure 3).

This method is based on procedures that require sophisticated equipment and more time. Therefore, we optimized the protocol of Cota-Sánchez et al. (2006) to develop a fast, reliable, and low-cost protocol for DNA extraction, suitable for PCR amplification from some herbarium specimens of the Papilionoideae. 
Table 1. Evaluation of samples extracted using Protocols A (Nucleospin Plant kit), B (modified - Doyle and Doyle, 1990), C (modified - Murray and Thompson, 1980), and D (modified - Cota-Sánchez et al., 2006), according to DNA quality, color, spectral absorbance ratio $\left(\mathrm{A}_{260280}\right)$, final concentration $(\mathrm{Cc}, \mathrm{ng} / \mu \mathrm{L})$, and polymerase chain reaction (PCR) amplification.

\begin{tabular}{|c|c|c|c|c|c|}
\hline Species & DNA quality $^{1}$ & Color $^{2}$ & $\mathrm{~A}_{260 / 280^{3}}{ }^{3}$ & $\mathrm{Cc}(\mathrm{ng} / \mu \mathrm{L})^{4}$ & $\mathrm{PCR}^{5}$ \\
\hline \multicolumn{6}{|l|}{ Protocol A } \\
\hline 1. Cicer insicum & 3 & NA & NA & 3 & 2 \\
\hline 2. Astragalus hymenostegis & 3 & NA & 2 & 3 & 2 \\
\hline 3. Chesneya astragalina & 3 & NA & 2 & 3 & 1 \\
\hline 4. Colutea buhsei & 3 & NA & NA & 3 & 2 \\
\hline 5. Halimodendrun halodendrun & 3 & NA & NA & 3 & 2 \\
\hline 6. Oxytropis aucheri & 2 & NA & 2 & 2 & 1 \\
\hline 7. Medicago rigidula & 3 & NA & 3 & 3 & 2 \\
\hline 8. Pisum sativum & 3 & NA & 2 & 3 & 2 \\
\hline 9. Vicia sativa & 2 & NA & 2 & 2 & 1 \\
\hline \multicolumn{6}{|l|}{ Protocol B } \\
\hline 1. Cicer insicum & 2 & 1 & 2 & 2 & 1 \\
\hline 2. Astragalus hymenostegis & 3 & 1 & 2 & 2 & 2 \\
\hline 3. Chesneya astragalina & 1 & 2 & 2 & 1 & 1 \\
\hline 4. Colutea buhsei & 1 & 3 & 3 & 1 & 1 \\
\hline 5. Halimodendrun halodendrun & 3 & 3 & NA & 3 & 2 \\
\hline 6. Oxytropis aucheri & 1 & 2 & 1 & 1 & 1 \\
\hline 7. Medicago rigidula & 1 & 1 & 2 & 1 & 1 \\
\hline 8. Pisum sativum & 2 & 1 & 1 & 2 & 1 \\
\hline 9. Vicia sativa & 1 & 1 & 1 & 1 & 1 \\
\hline \multicolumn{6}{|l|}{ Protocol C } \\
\hline 1. Cicer insicum & 1 & 1 & 1 & 3 & 1 \\
\hline 2. Astragalus hymenostegis & 2 & 1 & 1 & 3 & 1 \\
\hline 3. Chesneya astragalina & 1 & 1 & 1 & 2 & 1 \\
\hline 4. Colutea buhsei & 1 & 3 & 2 & 2 & 2 \\
\hline 5. Halimodendrun halodendrun & 2 & 2 & 2 & 3 & 1 \\
\hline 6. Oxytropis aucheri & 1 & 1 & 2 & 1 & 1 \\
\hline 7. Medicago rigidula & 1 & 1 & 1 & 2 & 1 \\
\hline 8. Pisum sativum & 1 & 1 & 1 & 2 & 1 \\
\hline 9. Vicia sativa & 1 & 1 & 1 & 1 & 1 \\
\hline \multicolumn{6}{|l|}{ Protocol D } \\
\hline 1. Cicer insicum & 1 & 1 & 1 & 3 & 1 \\
\hline 2. Astragalus hymenostegis & 2 & 1 & 1 & 3 & 1 \\
\hline 3. Chesneya astragalina & 1 & 1 & 1 & 1 & 1 \\
\hline 4. Colutea buhsei & 1 & 2 & 2 & 2 & 1 \\
\hline 5. Halimodendrun halodendrun & 2 & 1 & 1 & 2 & 1 \\
\hline 6. Oxytropis aucheri & 1 & 1 & 1 & 1 & 1 \\
\hline 7. Medicago rigidula & 1 & 1 & 1 & 2 & 1 \\
\hline 8. Pisum sativum & 1 & 1 & 1 & 3 & 1 \\
\hline 9. Vicia sativa & 1 & 1 & 1 & 3 & 1 \\
\hline
\end{tabular}

${ }^{1} 1$ = slightly degraded; 2 = moderate degraded; 3 = highly degraded. ${ }^{2} 1=$ colorless; $2=$ colored (yellowish); $3=$ brown (dark); $\mathrm{NA}=$ not applicable. ${ }^{3} 1=1.8 \leq \mathrm{A} \leq 1.89 ; 2=1.9 \leq \mathrm{A} \leq 2 ; 3=1.5 \leq \mathrm{A} \leq 1.79 .{ }^{4} 1=200 \mathrm{ng} /$ $\mu \mathrm{L} \leq \mathrm{Cc} ; 2=50 \mathrm{ng} / \mu \mathrm{L} \leq \mathrm{Cc}<200 \mathrm{ng} / \mu \mathrm{L} ; 3=\mathrm{Cc}<50 \mathrm{ng} / \mu \mathrm{L} .{ }^{5} \mathrm{PCR}$ amplification of $\operatorname{trn} \mathrm{L}$ intron and internal transcribed spacer region: $1=$ exhibited specific amplification; 2 = no amplification.

In the protocol presented, freezing tissue prior to homogenization was used to purge polyphenols (Lodhi et al., 1994). Furthermore, lower EDTA concentration was used. In agreement with Cota-Sánchez et al. (2006), we used a high salt concentration (1.4 M NACl) to prevent or diminish the precipitation of polysaccharides during the extraction step. NACl at concentrations of more than $0.5 \mathrm{M}$ together with CTAB is known to remove polysaccharides (Murray and Thompson, 1980; Fang et al., 1992). We increased organic solvent extraction time (chloroform:isoamyl alcohol) by inverting the tubes gently 50 times to obtain higher molecular weight DNA. The precipitation step was crucial in obtaining high-quality 
DNA. We reduced the precipitation time with isopropanol to eliminate precipitate contamination. This procedure does not involve a second DNA precipitation step. RNA smears were effectively removed by incubating tubes at $37^{\circ} \mathrm{C}$ for $30 \mathrm{~min}$ without RNase treatment. A final note should be made with regard to the amount of plant tissue used in the extraction. Although the expected DNA yield from a smaller sample amount should be lower, the possibilities for contaminants to coprecipitate with DNA are also lower, due to the fact that their saturation concentration during precipitation is less likely to be reached or exceeded (Figure 2B).

The isolated DNA was essentially free of contaminants based upon its lack of coloration and an $\mathrm{A}_{260 / 280}$ ratio of 1.8, which indicates pure genomic DNA (Brown, 1995). The isolated DNA was suitable for PCR amplification, which remained usable for at least 2 years when stored at $-20^{\circ} \mathrm{C}$ (Figure 3). The simplicity of the procedure makes it very practical for DNA extraction from historical herbarium specimens of the Papilionoideae.

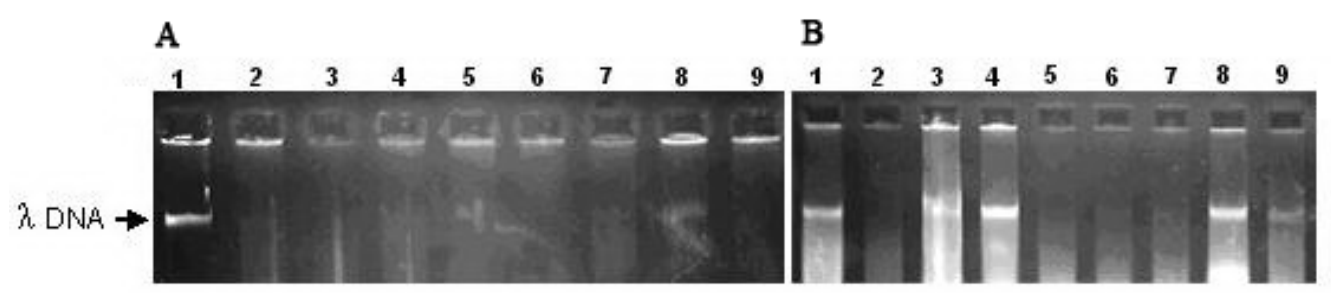

Figure 1. DNA of the different plant species on 1\% agarose gels, obtained using Protocols A and B. A. Total DNA extracted using Protocol A. Lane $1=$ Molecular marker; lane $2=$ Oxytropis aucheri; lane $3=$ Cicer insicum; lane $4=$ Astragalus hymenostegis; lane $5=$ Colutea buhsei; lane $6=$ Chesneya astragalina; lane $7=$ Medicago rigidula; lane 8 =Vicia sativa; lane $9=$ Pisum sativum. B. Total DNA extracted using Protocol B. Lane $1=$ Chesneya astragalina; lane 2 = Halimodendrun halodendrun; lane $3=$ Colutea buhsei; lane $4=$ Oxytropis aucheri; lane $5=$ Astragalus hymenostegis; lane $6=$ Pisum sativum; lane $7=$ Cicer insicum; lane $8=$ Vicia sativa; lane $9=$ molecular marker.

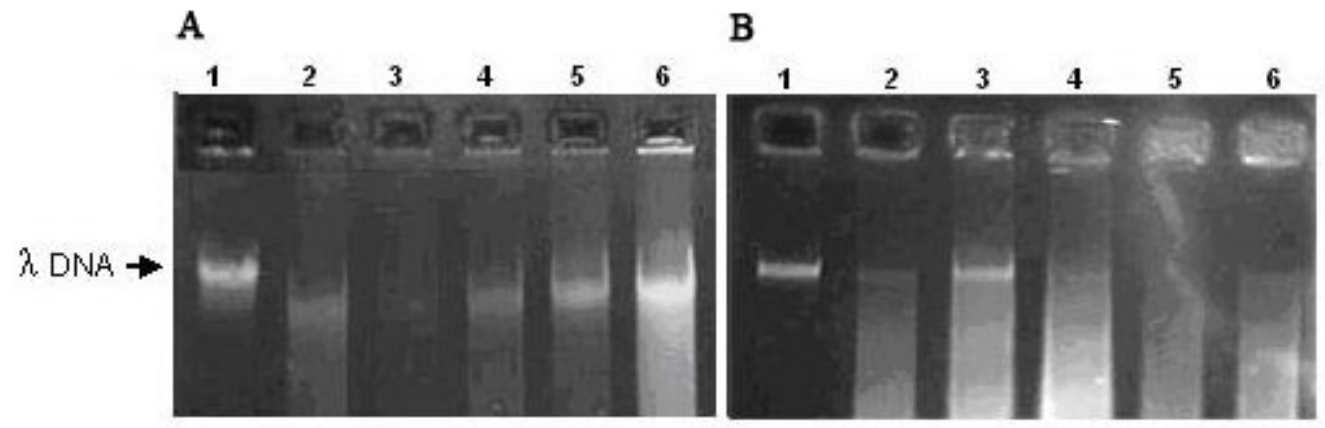

Figure 2. DNA of the different plant species on $1 \%$ agarose gels obtained using protocols $\mathrm{C}$ and $\mathrm{D}$. A. Total DNA extracted using protocol C. Lane $1=$ Molecular marker; lane $2=$ Pisum sativum; lane $3=$ Astragalus hymenostegis; lane $4=$ Medicago rigidula; lane $5=$ Chesneya astragalina; lane $6=$ Colutea buhsei . B. Total DNA extracted using protocol D. Lane 1 = Molecular marker; lane $2=$ Halimodendrun halodendrun; lane $3=$ Vicia sativa; lane $4=$ Pisum sativum; lane $5=$ Astragalus hymenostegis; lane $6=$ Colutea buhsei. 


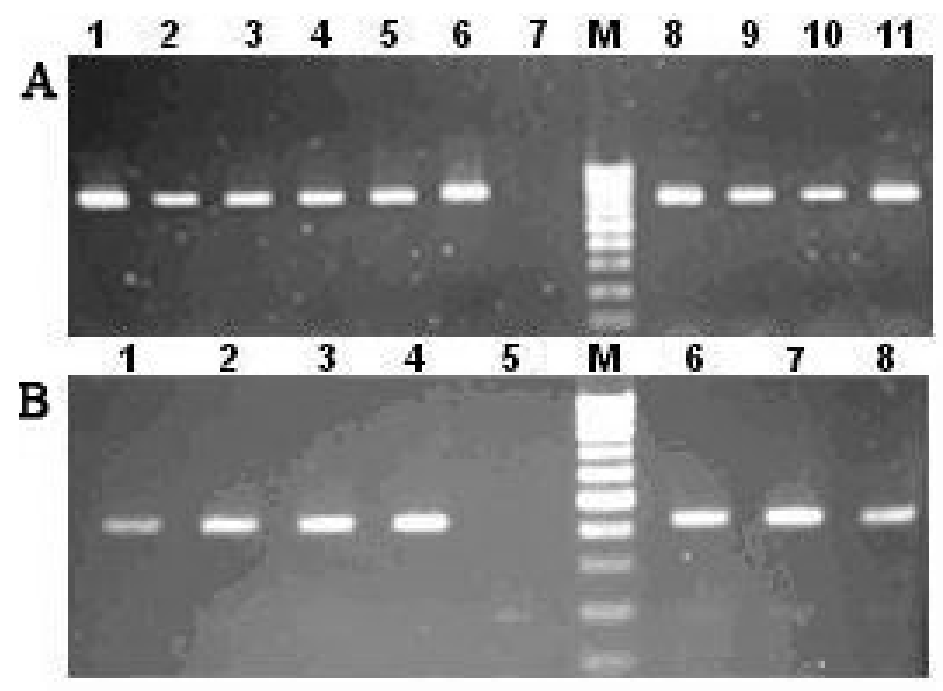

Figure 3. Nuclear internal transcribed spacer (ITS) and chloroplast $t r n \mathrm{~L} / \mathrm{F}$ region amplification of genomic DNA extracted by the following protocols. A. Amplification of ITS region of nrDNA extracted using Protocol C: Lane 1= Chesneya astragalina; lane $2=$ Halimodendrun halodendrun; lane $3=$ Colutea buhsei; lane $4=$ Oxytropis aucheri; lane 5 = Astragalus hymenostegis; lane $6=$ Pisum sativum; lane $7=$ a blank lane containing no genomic DNA; M $=100$-bp DNA ladder; and using protocol D: lane $8=$ Oxytropis aucheri; lane $9=$ Astragalus hymenostegis; lane $10=$ Pisum sativum; lane $11=$ Halimodendrun halodendrun. B. Amplification of $t r n \mathrm{~L} / \mathrm{F}$ region of cpDNA extracted using Protocol A: Lane 1 = Chesneya astragalina; lane 2 = Halimodendrun halodendrun; lane 3 = Colutea buhsei; lane $4=$ Oxytropis aucheri; lane $5=$ a blank lane containing no genomic DNA; $\mathrm{M}=100-\mathrm{bp}$ DNA ladder, and using Protocol B: lane $6=$ Chesneya astragalina; lane $7=$ Halimodendrun halodendrun; lane $8=$ Colutea buhsei .

\section{ACKNOWLEDGMENTS}

This project is undertaken in the framework of a Ph.D. thesis entitled "Phylogeny of the section Caprini (Astragalus, Fabaceae) based on molecular and morphological data" presented by M. Riahi. This project was funded by the Research Council of the University of Tehran.

\section{REFERENCES}

Ausubel M, Brent R, Kingston RE, Moore DD, et al. (Editors) (1994). Current Protocols. In: Molecular Biology. John Wiley and Sons, New York, 201-214.

Brown TA (1995). Gene Cloning: An Introduction. Chapman and Hall, London.

Cota-Sánchez JH, Remarchuk K and Ubayasena K (2006). Ready-to-use DNA extracted with a CTAB method adapted for herbarium specimens and mucilaginous plant tissue. Plant Mol. Biol. Rep. 24: 161-167.

Doyle JJ and Doyle JL (1990). Isolation of plant DNA from fresh tissue. Focus 12: 13-15.

Drábková L, Kirschner J and Vlcek C (2002). Comparison of seven DNA extraction and amplification protocols in historical herbarium specimens of Juncaceae. Plant Mol. Biol. Rep. 20: 161-175.

Fang G, Hammar S and Grumet R (1992). A quick and inexpensive method for removing polysaccharides from plant genomic DNA. Biotechniques 13: 52-54, 56.

Lodhi MA, Ye G-N, Weeden NF and Reisch BI (1994). A simple and efficient method for DNA extractions from grapevine 
cultivars and Vitis species. Plant Mol. Biol. Rep. 12: 6-13.

Mabberley DJ (1997). The Plant Book. A Portable Dictionary of the Vascular Plants. Cambridge University Press, Cambridge.

Murray MG and Thompson WF (1980). Rapid isolation of high molecular weight plant DNA. Nucleic Acids Res. 8: 43214325.

Pirttilä AM, Hirsikorpi M, Kämäräinen T and Jaakola L (2001). DNA isolation methods for medicinal and aromatic plants. Plant Mol. Biol. Rep. 19: 273a-273f.

Rogers SO (1994). Phylogenetic and Taxonomic Information from Herbarium and Mummified DNA. In: Conservation of Plant Genes II: Utilization of Ancient and Modern DNA (Adams RP, Miller J, Golenberg E and Adam JE, eds.). Missouri Botanical Gardens Press, Monogr. Vol. 48, St. Louis, 47-67.

Sytsma K, Givnish TJ, Smith JF and Hahn WJ (1993). Collection and Storage of Land Plant Samples for Macromolecular Comparisons. In: Methods in Enzymology - Molecular Evolution: Producing the Biochemical Data (Zimmer EA, White TJ, Cann RL and Wilson AC, eds.). Academic Press, San Diego, 23-38.

Taberlet P, Gielly L, Pautou G and Bouvet J (1991). Universal primers for amplification of three non-coding regions of chloroplast DNA. Plant Mol. Biol. 17: 1105-1109.

White TJ, Burus TD, Lee SB and Taylor JW (1990). Amplification and Direct Sequencing of Fungal Ribosomal RNA Genes for Phylogenetics. In: PCR Protocols: A Guide to Methods and Applications (Innis MA, Gelfand DH, Sninsky JJ and White TJ, eds.). Academic Press, New York, 315-322.

Appendix. Species and tribes from herbarium specimens.

Tribe Cicereae

Cicer insicum (Willd.) K. Maly.; Azarbaiejan, Marand; 763; 1951.

Tribe Galegea

Astragalus hymenostegis Fisch. \& C.A. Mey; Azarbaiejan, Marand; 763; 1955.

Chesneya astragalina jaub. \& spach; Tehran, Eivanakey; 5551; 2000.

Colutea buhsei (Boiss.). Shap.; Gorgan Park-e Golestan; 3565; 1990.

Halimodendrun halodendrun (Pall.) Voss.; Tehran, Karaj; 284; 1950.

Oxytropis aucheri Boiss.; Golestan, Golestan Park; 24412; 2002.

Tribe Trifolieae

Medicago rigidula (L.) All.; Azarbaiejan, Khoy; 1181; 1960.

Tribe Vicieae

Pisum sativum L.; Esfahan; 324; 1951.

Vicia sativa L. Kurdestan, Sanandaj; 56741; 2005.

Each entry includes species, locality, voucher specimen, and age of herbarium specimens. 